\title{
Demographic types of small cities in Poland
}

\begin{abstract}
The aim of the study was to determine the demographic types of all small cities in Poland in 2013 and to identify the standards of their spatial diversity. The following questions were posed: Which demographic types are dominant among the small cities of Poland? Is there a relation between a specific demographic type and the size of the city? Does the structure of small cities according to their demographic types relate to their distance from main roads and urban agglomerations? The study applied the Webb's typology, the K. Doi leading element method, the departure from average indicator, and the nonparametric Chi squared test. The spatial regularities were identified based on the created maps.

The results of the study show that small cities of Poland in 2013 were represented by all demographic types, but most of them were regressive. They were established in $80 \%$ of small cities. The main element determining the population trends of small cities was the negative migration balance, which was observed in $80 \%$ of the surveyed areas. It was also established that the population of small cities has a slight impact on population trends. The most important aspect of their development is the distance from agglomerations and main roads.
\end{abstract}

Keywords

Small cities $\cdot$ demographic types $\cdot$ Webb's typology

(C) University of Warsaw - Faculty of Geography and Regional Studies

\author{
Wioletta Kamińska ${ }^{1}$ \\ Mirosław Mularczyk ${ }^{2}$ \\ 'Institute of Geography \\ The Jan Kochanowski University in Kielce \\ e-mail: wioletta.kaminska@ujk.edu.pl \\ 2Institute of Geography \\ The Jan Kochanowski University in Kielce \\ e-mail: miroslaw.mularczyk@ujk.edu.pl
}

Received: 31 October 2014

Accepted: 19 November 2014
Introduction

At the turn of the $20^{\text {th }}$ and $21^{\text {st }}$ centuries, several regions of the world experienced strongly diverse population dynamics. Certain countries recorded a growth of demographic potential while others saw a considerable population drop (Fésüs et al. 2008). The internal demographic processes of the individual countries were also confirmed to be very diverse. The big urban agglomerations usually had high population growth indicator. The growing demographic potential benefited from the concentration of business activity and the well-developed labour market (Duranton \& Puga 2004). Meanwhile, small cities and rural areas were more exposed to the economic crisis and depopulation. This mainly concerned the peripheral areas of the main centres of regional development and communication systems (Brezzi et al. 2011).

The shrinking population potential entails negative changes to both the demographic structure (e.g. aging of the society, disturbed structure of population according to gender) and the economic structure (e.g. reduced labour reserves, limited industrial development). These changes hamper the sustainable development of the individual administrative entities, especially those of small cities. This not good, because the smallest urban areas play a significant role in establishing the prosperity of not only their population, but the rural community around them as well. These areas host market and non-market services and technical and social infrastructure, which provide for the concentration of the local innovation and production potential (Knox et al. 2009). Small urban areas are a crucial part of avoiding rural depopulation and of regional sustainable development and territorial cohesion (Exploring Urban Futures in European Cities... 2011).

The discussion concerning the population changes in Poland often referred to metropolises (Bogacz \& Żłobińska 2005; WiniarczykRaźniak \& Raźniak 2012), agglomeration (Górecka \& Kozieł 2004), and medium-sized cities (Runge 2013). The smallest urban units rarely attracted scientific interest. The sparse research in this scope concerned selected cities in specific regions (e.g. Kwiatek-Soltys 2000, 2004; eds Bartosiewicz \& Marszał 2011). There are still no studies concerning the demographic trends of the entire group of small urban areas in Poland.

Therefore, the objective of this study is to define the demographic types of all small cities in Poland in 2013 and identify the regularities of their spatial diversity. It attempts to answer the following research questions:

1. Which are the dominating demographic types of small cities in Poland?

2. Is there a relation between a specific demographic type and the size of the city?

3. Does the structure of small cities according to their demographic types relate to their position concerning main roads and urban agglomerations?

The study follows the Central Statistical Office in assuming that small cities are areas with administrative city rights and population under 20 000. Similar assumptions in Polish geographical 
research were made by Dziewoński 1962; Heffner \& Czarnecki 2004. Additionally, the group of small cities was divided into four categories according to size: population up to 1999 , between 2000 and 4999, between 5000 and 99 999, and between 10000 and 19999.

\section{Methods}

Several research methods and techniques were applied for the proper realisation of the established objectives. The demographic types of small cities were determined with the Webb's typology, which is based on natural increase rate and migration balance. This typology allows to determine the cause for changes in the population of the analysed cities. 8 demographic types were established and assigned with the letters from $\mathrm{A}$ to $\mathrm{H}$. The first four (A, B, C, D) are considered as developmental with growing population, the next four $(E, F, G, H)$ are regressive with dropping population. The individual types have different relations between natural increase and migration balance:

A- positive natural increase exceeds negative migration balance,

B - positive natural increase exceeds positive migration balance,

C - positive natural increase is exceeded by positive migration balance,

D - positive migration balance exceeds negative natural increase,

$\mathrm{E}$ - negative natural increase is not compensated by positive migration balance,

$\mathrm{F}$ - negative natural increase exceeds negative migration balance,

$G$ - negative natural increase does not exceed negative migration balance,

$\mathrm{H}$ - negative migration balance is not compensated by positive natural increase.

The $\mathrm{K}$ Doi procedure was used to define the leading demographic types of the analysed cities. The procedural algorithm covered the following (Runge 2007):

- expressing the structures as percentages,

- ordering the structures from biggest to smallest,

- creating the cumulated series structure,

- comparing successive values from the cumulated series with their corresponding critical values presented in the statistical tables.

The elements established as leading were those with their share in the structure exceeding their adequate critical value.

The study also employs the departure from average indicator, the purpose of which is to establish the differences in the structure of small cities according to the demographic types in the subgroups with various population and diverse location and parallel structure defined for the entire group of surveyed settlements.

The indicator is calculated by the following formula:

$W_{O}={ }_{Z o}^{Z t} * 100 \%$

where:

$W_{O}$ - total departure from average indicator,

$Z t$ - percentage of the given demographic type in the specific subgroup of small cities (according to size and location),

$\mathrm{Zo}$ - percentage share of the given demographic type in the entire group of small cities.

The indicator may have the value lower than, greater than, or equal to $100 \%$. If it is lower than $100 \%$, it means that the percentage share of the specific demographic type in the given subgroup (by size and distance from main roads and urban agglomerations) is lower than that in the structure of the entire group of the surveyed cities. In this case, we are dealing with a deficiency of cities with a specific demographic type. In turn, a departure indicator value greater than $100 \%$ indicates the overrepresentation of the cities of a given demographic type. If the indicator is at $100 \%$, the parallel elements of both structures, the city group and subgroups, are identical.

The Chi squared nonparametric test was used to survey the relations between the city sizes expressed in population and the demographic types.

The spatial regularities were identified based on the created maps.

For purposes of surveying the relations between the demographic types of the small cities and their location along roads with considerable international and domestic significance, the surveyed settlements were divided into two subgroups of those located near communication routes (within $5 \mathrm{~km}$ ) and those distant from them. The physical distance from road corridors is the most natural and simple measure of relations between small cities and various areas. As shown by Veneri and Ruiz (2013), these relations cover demographic traffic (migrations), access roads, and flows of production factors.

The surveyed settlements were also divided into two subgroups in order to identify the potential impact of urban agglomerations on the population trends of small cities: those located within and beyond the impact zone of agglomerations. It was assumed that the impact zone of agglomerations covers small cities within $30 \mathrm{~km}$ of cities with population between 200 thousand and one million (Białystok, Bydgoszcz, Częstochowa, Gdańsk, Gdynia, Kraków, Lublin, Łódź, Poznań, Radom, Szczecin, Wrocław) and within $60 \mathrm{~km}$ of cities with population over one million (Warszawa and the Upper Silesian conurbation). The assumed distances approximately correspond to the sizes of the suburban zones (Domański 2001). The study assumes that the agglomerations and small cities located near them are strongly related (Dijstra \& Poelman 2008; Veneri \& Ruiz 2013). A suburban location can favour positive effects such as the spreading of economic and population growth, as well as negative ones, including the flushing of development potential.

The survey of dependencies between the demographic types of the small cities and their distance from main roads and urban agglomerations did not involve statistical tests because of the dichotomous division of the group of the surveyed areas and the lack of normal distribution. For this reason, the spatial regularities were established on the basis of quantitative analysis.

\section{Small city population issues - literature review}

The interest of geographers in small cities has been diverse and had two periods of intensification (Dziewoński 1983). The first was during the 1950s and 1960s, the second was at the turn of the $10^{\text {th }}$ and $21^{\text {st }}$ centuries.

After World War II, small cities were usually analysed either together with rural areas or with other cities. Many studies analysed population changes by referring to theoretical concepts, including the demographic transfer theory or the prosperity cycle theory (Easterlin 1962). Plenty of focus was also place on depopulation, determination of the factors causing shrinking population, and the negative consequences of depopulation (Ramsey 1967; Hägerstrand 1957).

The issues of small city potential transformation were once again addressed in the late $20^{\text {th }}$ century, when many states of Central and Eastern Europe recorded considerable population drops. The research was dominated by the dichotomous approach, which saw the population changes analysed in light of the coreperiphery theory (Parr 1973; Partridge et al. 2007). It was generally 
MISCELLANEA GEOGRAPHICA - REGIONAL STUDIES ON DEVELOPMENT

Vol. 18 • No. 4 • 2014 • pp. 24-33 • ISSN: 2084-6118 • DOI: 10.2478/mgrsd-2014-0031

Table 1. Size structure of Polish cities in 2013

\begin{tabular}{|c|c|c|c|c|}
\hline $\begin{array}{c}\text { City size by population } \\
\text { [thousands] }\end{array}$ & Number of cities & $\begin{array}{c}\text { Population } \\
\text { [millions] }\end{array}$ & $\begin{array}{c}\text { \% share in city } \\
\text { number }\end{array}$ & $\begin{array}{c}\text { \% share in city } \\
\text { population }\end{array}$ \\
\hline $\begin{array}{c}\text { very big } \\
(1000 \text { and up })\end{array}$ & 1 & 1.7 & 0.1 & 7.4 \\
\hline $\begin{array}{c}\text { big } \\
(200-999.9)\end{array}$ & 15 & 5.9 & 1.7 & 25.5 \\
\hline $\begin{array}{c}\text { medium } \\
(20-19.9)\end{array}$ & 206 & 10.6 & 22.7 & 45.7 \\
\hline $\begin{array}{c}\text { small } \\
\text { (up to 19.9) }\end{array}$ & 686 & 5.0 & 75.6 & 21.4 \\
\hline Total & 908 & 23.2 & 100 & 100 \\
\hline
\end{tabular}

Source: personal calculations based on Central Statistical Office of Poland 2014

assumed that the cores (urban regions) presented population growth, while the peripheries (small cities and rural areas) usually experienced population drops. However, the demographic trends within the peripheral areas were also diverse and conditioned by numerous factors. There was a population growth observed in cities located within metropolitan areas (Čermák, Hampl \& Müller 2009, Population and the American Future 1972) and along main communication routes (The Future of Shrinking Cities .... 2009). Other factors beneficial to concentrated population included aboveaverage climate advantages (Cheshire\& Magrini 2004) and the associated recreational advantages (Domhardt \& Troeger-Wei 2009). Meanwhile, areas with low economic development presented dropping demographic potential. This factor drove the younger part of the community out of small cities (Daniels \& Lapping 1987; Fuguitt, Brown \& Beale 1989; Fuguitt \& Heaton 1995; Johnson 2006, Kantor-Pietraga, Krzysztofik \& Runge 2012).

The intensification of the aforementioned factors was spatially diverse and conditioned by the economic advancement of a given region. In well developed countries, the population processes in small cities were frequently analysed for relation to the growth of labour output in agriculture, which benefited the outflow of the labour force. Such trends were identified in e.g. central Australia (Tonts 1996; Gabriel 2002; Alston 2004).

In developing countries, the dynamic development of the biggest cities entailed a population outflow from cities dominated by agriculture. The publications analysed the causes and consequences of the shrinking demographic potential and pointed to ways of slowing down the negative transformations (e.g. ed. Baker 1988; Choguill 1989; Titus \& Hinderink 2002; Tacoli 2004).

Besides issues related to the depopulation of post-industrial cities, the literature of eastern Europe started to recognise the growth of the smallest urban areas as the result of immigration abroad. Authors presenting these issues included: Fonseca 2008; Graeme \& Morén-Alegret 2008; Morén-Alegret 2008.

The depopulation of small cities in Central and Eastern Europe during the system transformations was noted by Glock (2006), Mykhnenko \& Turok (2008), Kamarai (2011), Kantor-Pietraga (2014), Kantor-Pietraga, Krzysztofik \& Runge (2012). These authors indicated that the negative demographic processes were experienced mainly by the smallest industrial urban areas. The restructuring processes accelerating the bankruptcy of numerous workplaces composed a factor beneficial to population outflow.

Small cities within the urban settlement network of Poland

In 2013, there were 686 small cities (with population under 20 thousand) in Poland, which composed approximately $75 \%$ of all of the country's cities. They composed over $20 \%$ (5 million) of urban population (Tab. 1). Meanwhile, the group of medium, big, and very big cities covered the total of 222 cities with the collective population of 18.3 million. This composed adequately $25 \%$ of the total urban areas and almost $80 \%$ of urban population (Tab. 1).

The population and functions of the small urban areas were diverse. The smallest city had the population of 906 . The surveyed cities were based mainly on agriculture (Bagiński 1998, Kozłowski 2007) and services, including administration, trading, tourism, and health resorts (Heffner 2008), rarely industrialism (Kachniarz et al. 1996).

In the analysed year, the size structure of small cities was diverse. The most areas had the population between 2 and 5 thousand. There were 268 of them, which composed almost $40 \%$ of the total. They had the collective population of 887.1 thousand, i.e. almost $18 \%$ of the total small city population (Tab. 2).

Areas with population between 5 and 10 thousand and areas with population between 10 and 20 thousand had a similar share in the city numbers. The former composed $26.4 \%$ of the surveyed group, the latter $27.3 \%$. Considering the population, they composed adequately $25.8 \%$ and $54.7 \%$ of the total small city population (Tab. 2).

The areas with population under 2 thousand composed the smallest group, as there were 50 of them in 2013 , i.e. $7.3 \%$ of the total small cities in Poland. Their population was over 80 thousand, or $1.7 \%$ of that of the analysed settlement group (Tab. 2).

Demographic types of small cities in Poland

All Webb's demographic types were represented among the small cities in Poland. The regressive ones (E, F, G, H) composed the majority as they covered $78 \%$ of the analysed settlements. The remaining $22 \%$ of the small cities were classified as progressive (A, B, C, D) (Fig. 1).

The leading elements in the structure of the analysed settlements were types $\mathrm{F}, \mathrm{G}$, and $\mathrm{H}$. The greatest percentage share $(33.8 \%)$ was composed by urban areas classified as type G. Almost $25 \%$ of the small cities represented type $H$, while $13 \%$ represented type $F$ (Tab. 3).

The remaining demographic types of small cities in Poland were not considered as leading elements. They included one regressive type $(E)$ and all progressive types (A, B, C, D). Type $E$ covered slightly more than $6 \%$ of the cities. The most progressive settlements were those of type A $(7.9 \%)$. Type C presented a lower representation $(6.1 \%)$ and the smallest group of small cities was composed of type B areas (3.0\%) (Tab. 3). 
Table 2. Size structure of small Polish cities in 2013

\begin{tabular}{|c|c|c|c|c|}
\hline City size by population & Number of cities & $\begin{array}{c}\text { Population } \\
\text { [thousands] }\end{array}$ & $\begin{array}{c}\% \text { share in small city } \\
\text { number }\end{array}$ & $\begin{array}{c}\% \text { share in small city } \\
\text { population }\end{array}$ \\
\hline do 1999 & 50 & 82.9 & 7.29 & 1.67 \\
\hline $2000-4999$ & 268 & 887.1 & 39.07 & 17.86 \\
\hline $5000-9999$ & 181 & 1281.9 & 26.38 & 25.81 \\
\hline 10 000-19 999 & 187 & 2715.6 & 27.26 & 54.67 \\
\hline total & 686 & 4967.5 & 100 & 100 \\
\hline
\end{tabular}

Source: personal calculations based on Central Statistical Office of Poland 2014

Table 3. Demographic types of small cities in Poland in 2013

\begin{tabular}{|c|c|c|}
\hline $\begin{array}{c}\text { Demographic } \\
\text { types }\end{array}$ & Number of cities & \% share \\
\hline A & 54 & 7.9 \\
\hline B & 21 & 3.0 \\
\hline C & 42 & 6.1 \\
\hline D & 34 & 5 \\
\hline E & 43 & 6.3 \\
\hline F & 89 & $\mathbf{1 3}$ \\
\hline G & 232 & $\mathbf{3 3 . 8}$ \\
\hline H & 171 & $\mathbf{2 4 . 8}$ \\
\hline Total, including: & 686 & 100.0 \\
\hline progressive & 151 & 22.1 \\
\hline regressive & 535 & 77.9 \\
\hline
\end{tabular}

*dominating demographic types of small cities according to the K. Doi procedure in bold

Source: personal calculations based on Central Statistical Office of Poland 2014

Demographic types of small cities compared to their population The survey of the statistical relation between the demographic types and the sizes of the covered cities applied the Chi-squared compliance test. The performed procedures failed to show any statistically relevant relation between the properties.

The applied K. Doi procedure identified the leading elements (demographic types) of the individual size groups of the cities. $78 \%$ of the smallest urban areas with population under 2 thousand were regressive, while $22 \%$ were progressive (Fig. 1). The leaders were three regressive types (F, G, H) (Tab. 4), which covered the total of $70 \%$ of the surveyed centres. The comparison of the small city demographic type structure within this size group with the structure of all surveyed settlements shows that the shares of both the progressive and regressive areas were similar. However, the progressive types demonstrated a great overrepresentation of type D small cities, for which the total departure from average factor was $161.4 \%$. Meanwhile, the regressive type group had a clearly higher share of type $\mathrm{F}$ areas than that in the structure of all cities. In this case, the total departure from average indicator was $169.6 \%$ (Tab. 4).

Among cities with population between 2 and 5 thousand, $74.2 \%$ settlements were deemed regressive and $25.8 \%$ were

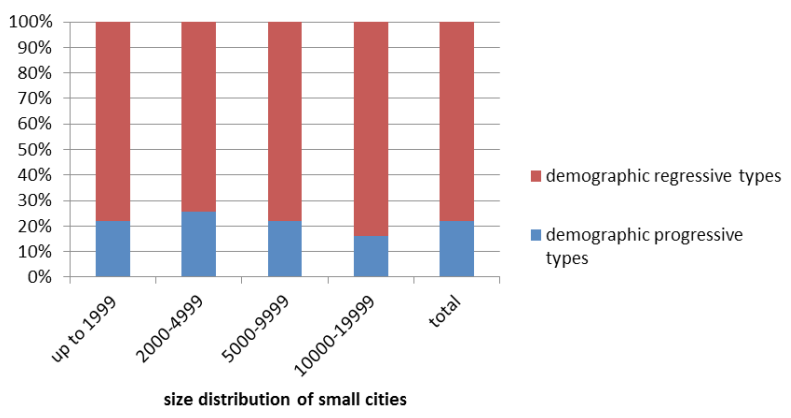

Figure 1. Percentage share of Polish progressive and regressive small city types by population in 2013

Source: personal research

deemed progressive (Fig. 1). The elements leading the structure were all of the regressive types $(E, F, G, H)$ and the progressive type A (8.2\%) (Tab. 3).

The structure's analysis according to the demographic types of this city size group shows that the share of progressive types was slightly higher (total departure from average indicator $117.2 \%)$ and the share of regressive ones was lower (95.1\%) in relation to the structure of all analysed cities (Tab. 4)

Almost $78 \%$ settlements with population between 5 and 10 thousand represented regressive types, while progressive types were represented by $22 \%$ (Fig. 1). The leading elements in this size group of the analysed areas were both regressive types ( $F, G, H-72.4 \%$ total) and the progressive type $A(11.6 \%)$. The demographic structure of this city size group was most similar to the cities in general.

Small areas with population between 10 and 20 thousand had the greatest share of regressive cities, which composed almost $84 \%$ of all of the areas analysed within this size class. Therefore, progressive types represented slightly over $16 \%$ of such cities (Fig. 1). The leading elements were two regressive types: G $39.8 \%$, and $\mathrm{H}-32.3 \%$ (Tab. 3). The share of progressive cities in this size group departed considerably from the parallel share in the entire city group. The departure from average indicator was $73.6 \%$. The greatest difference appeared for type A areas, which composed $3.8 \%$ of this group and $7.9 \%$ in the entire group of small cities (total departure from average indicator $-48.3 \%$ ).

Demographic types of small cities and their distance from main roads

Communication access is commonly considered as one of the most important factors affecting the attractiveness of small city location and settlement. In turn, this attractiveness affects the demographic structures. This is the reason for the attempt to 
MISCELLANEA GEOGRAPHICA - REGIONAL STUDIES ON DEVELOPMENT

Vol. $18 \cdot$ No. 4 • 2014 • pp. 24-33 • ISSN: 2084-6118 • DOI: 10.2478/mgrsd-2014-0031

Table 4. Structure of small cities according to demographic type and population

\begin{tabular}{|c|c|c|c|c|c|c|c|c|c|}
\hline \multirow[b]{3}{*}{$\begin{array}{c}\text { Demographic } \\
\text { types of small } \\
\text { cities }\end{array}$} & \multicolumn{9}{|c|}{ Small cities according to population } \\
\hline & \multicolumn{2}{|c|}{ Up to 1999} & \multicolumn{2}{|c|}{ Between 2000 do 4999} & \multicolumn{2}{|c|}{ Between 5000 and 9999} & \multicolumn{2}{|c|}{ Between 10000 do 19999} & \multirow{2}{*}{\begin{tabular}{|c} 
Total \\
Share \% \\
Total \\
average
\end{tabular}} \\
\hline & $\begin{array}{c}\text { Share } \\
\%\end{array}$ & $\begin{array}{c}\text { Total departure } \\
\text { from average } \\
\text { indicator } \\
{[\%]}\end{array}$ & $\begin{array}{c}\text { Share } \\
\%\end{array}$ & $\begin{array}{c}\text { Total departure } \\
\text { from average } \\
\text { indicator } \\
{[\%]}\end{array}$ & $\begin{array}{c}\text { Share } \\
\%\end{array}$ & $\begin{array}{c}\text { Total departure } \\
\text { from average } \\
\text { indicator } \\
{[\%]}\end{array}$ & $\underset{\%}{\text { Share }}$ & $\begin{array}{c}\text { Total departure } \\
\text { from average } \\
\text { indicator } \\
{[\%]}\end{array}$ & \\
\hline A & 8.0 & 101.6 & 8.2 & 104.2 & 11.6 & 147.4 & 3.8 & 48.3 & 7.9 \\
\hline B & 2.0 & 66.7 & 4.5 & 150.0 & 1.1 & 36.7 & 3.2 & 106.7 & 3.0 \\
\hline $\mathrm{C}$ & 4.0 & 65.3 & 7.5 & 122.5 & 5 & 81.7 & 5.4 & 88.2 & 6.1 \\
\hline $\mathrm{D}$ & 8.0 & 161.4 & 5.6 & 113.0 & 4.4 & 88.8 & 3.8 & 76.7 & 5.0 \\
\hline$E$ & 8.0 & 127.6 & 8.2 & 130.8 & 5.5 & 87.7 & 3.8 & 60.6 & 6.3 \\
\hline $\mathrm{F}$ & 22.0 & 169.6 & 13.8 & 106.4 & 14.4 & 111.0 & 8.1 & 62.4 & 13.0 \\
\hline$G$ & 26.0 & 76.9 & 32.1 & 94.9 & 32.6 & 96.4 & 39.8 & 117.7 & 33.8 \\
\hline $\mathrm{H}$ & 22.0 & 88.3 & 20.1 & 80.6 & 25.4 & 101.9 & 32.3 & 129.6 & 24.9 \\
\hline $\begin{array}{c}\text { Total, } \\
\text { progressive } \\
(\mathrm{A}, \mathrm{B}, \mathrm{C}, \mathrm{D})\end{array}$ & 22.0 & 99.9 & 25.8 & 117.2 & 22.1 & 100.4 & 16.2 & 73.6 & 22.0 \\
\hline $\begin{array}{l}\text { Total, } \\
\text { regressive } \\
(\mathrm{E}, \mathrm{F}, \mathrm{G}, \mathrm{H})\end{array}$ & 78.0 & 100.0 & 74.2 & 95.1 & 77.9 & 99.9 & 83.8 & 107.5 & 78.0 \\
\hline
\end{tabular}

*dominating demographic types of small cities according to the $\mathrm{K}$. Doi procedure in bold

Source: personal calculations based on Central Statistical Office of Poland 2014

answer the question on if the structure of small cities according to their demographic types relates to their distance from main roads. The city analyses were divided into two groups: those located along communication routes and those located far from them. The first group covered 274 (40\%) and the second covered $412(60 \%)$ of the analysed areas.

However, both of the analysed city groups were dominated by regressive type settlements.

Over $75 \%$ of the areas located along the assumed communication trails were regressive, almost $25 \%$ were progressive. The structure was led by small cities type $F$ and $G$, followed by type $\mathrm{H}$ (Tab. 5; Fig. 2).

Almost $80 \%$ of the areas located far from domestic and international roads were established as regressive and just over $20 \%$ as progressive. The leading settlements of the group were $\mathrm{G}$ and $\mathrm{H}$.

The comparison of the demographic type structure of areas located near roads with the structure of all surveyed settlements shows that the share of regressive cities was slightly lower (departure from average indicator $-96.3 \%$ ). It was slightly higher $(102.3 \%)$ for cities located far from the communication routes covered by the research, but these differences are not significant.

The share of progressive urban areas in the structures of cities located near roads was greater in relation to the share in the entire surveyed group (total departure from average factor - $113.2 \%)$. The greatest departure from the average for the total surveyed areas $(150.8 \%)$ was shown by cities classified as type $\mathrm{C}$. The share of progressive areas in cities located far from communication routes in relation of the surveyed settlements was lower (91.8\%).
Demographic types of small cities and their location in relation to urban agglomerations

The population processes of small cities should also be examined in relation to their distance from the biggest urban areas. For this purpose, the analysis covered the diverse demographic types of small cities depending on their distance from urban agglomerations and saw the separation of two subgroups: areas located within the impact zone of the country's biggest cities and areas located outside of them. The first subgroup included 118 $(17.2 \%)$ and the second included $568(82.8 \%)$ of the analysed areas. Both of the surveyed subgroups were dominated by regressive settlements.

Considering small cities located within the impact zone of the agglomerations, almost $60 \%$ were regressive, while slightly over $40 \%$ were progressive. Their structure was led by both the regressive types $\mathrm{G}$ and $\mathrm{H}$ and the progressive type $\mathrm{C}$ (Tab. 6).

$82 \%$ of the centres located outside of the impact zones of agglomerations were qualified as regressive and $18 \%$ were qualified as progressive. This group was led by type $\mathrm{G}$ and $\mathrm{H}$ settlements (Tab. 6).

It should be noted that over $32 \%$ of the cities qualified as progressive were located in suburban zones. The parallel share of regressive cities was only $13 \%$. This confirms the thesis that location within the impact zones of agglomerations developed positive demographic trends. This was also proven by the results of the analysis of the total departure from average for both of the surveyed city subgroups.

The comparison of the demographic type structure of areas located within the impact zones of agglomerations with the structure of all surveyed settlements showed that the share 
Table 5. Demographic types of small cities in Poland by location in relation to roads with international and domestic significance

\begin{tabular}{|c|c|c|c|c|c|}
\hline \multirow{3}{*}{$\begin{array}{l}\text { Demographic types } \\
\text { of small cities }\end{array}$} & \multicolumn{4}{|c|}{ Small cities by location: } & \multirow{3}{*}{$\begin{array}{c}\text { Share } \% \\
\text { Total average }\end{array}$} \\
\hline & \multicolumn{2}{|c|}{ Near roads } & \multicolumn{2}{|c|}{ Far from roads } & \\
\hline & Share $\%$ & $\begin{array}{c}\text { Total departure } \\
\text { from average } \\
{[\%]}\end{array}$ & Share $\%$ & $\begin{array}{c}\text { Total departure } \\
\text { from average } \\
{[\%]}\end{array}$ & \\
\hline$A$ & 8.8 & 111.4 & 7.3 & 92.4 & 7.9 \\
\hline$B$ & 2.2 & 73.3 & 3.6 & 120.0 & 3.0 \\
\hline $\mathrm{C}$ & 9.2 & 150.8 & 4.2 & 68.9 & 6.1 \\
\hline $\mathrm{D}$ & 4.7 & 94.0 & 5.1 & 102.0 & 5 \\
\hline$E$ & 5.8 & 92.1 & 6.6 & 104.8 & 6.3 \\
\hline $\mathrm{F}$ & 13.5 & 103.8 & 12.6 & 96.9 & 13.0 \\
\hline G & 28.8 & 85.2 & 37.1 & 109.8 & 33.8 \\
\hline $\mathrm{H}$ & 27.0 & 108.4 & 23.5 & 94.4 & 24.9 \\
\hline $\begin{array}{l}\text { Total, progressive } \\
(A, B, C, D)\end{array}$ & 24.9 & 113.2 & 20.2 & 91.8 & 22.0 \\
\hline $\begin{array}{c}\text { Total, regressive } \\
(E, F, G, H)\end{array}$ & 75.1 & 96.3 & 79.8 & 102.3 & 78.0 \\
\hline Total & 100 & $x$ & 100 & $x$ & 100 \\
\hline
\end{tabular}

*dominating demographic types of small cities according to the K. Doi procedure in bold Source: personal calculations based on Central Statistical Office of Poland 2014

Table 6. Demographic types of small Polish cities by location in relation to big cities

\begin{tabular}{|c|c|c|c|c|c|}
\hline \multirow{3}{*}{$\begin{array}{l}\text { Demographic } \\
\text { types of small } \\
\text { cities }\end{array}$} & \multicolumn{4}{|c|}{ Small cities by location: } & \multirow{3}{*}{$\begin{array}{c}\text { Share \% } \\
\text { Total } \\
\text { average }\end{array}$} \\
\hline & \multicolumn{2}{|c|}{ Suburban zone } & \multicolumn{2}{|c|}{ Outside of suburban zone } & \\
\hline & Share \% & $\begin{array}{c}\text { Total departure from } \\
\text { average } \\
{[\%]}\end{array}$ & Share \% & $\begin{array}{c}\text { Total departure from } \\
\text { average } \\
{[\%]}\end{array}$ & \\
\hline A & 6.8 & 85.8 & 8.1 & 102.5 & 7.9 \\
\hline$B$ & 5.9 & 197.7 & 2.5 & 82.2 & 3.0 \\
\hline $\mathrm{C}$ & 17.8 & 291.7 & 3.7 & 60.6 & 6.1 \\
\hline $\mathrm{D}$ & 11.0 & 220.3 & 3.7 & 73.9 & 5 \\
\hline$E$ & 6.8 & 107.6 & 6.2 & 97.8 & 6.3 \\
\hline $\mathrm{F}$ & 11.0 & 84.7 & 13.4 & 102.9 & 13 \\
\hline G & 21.2 & 62.7 & 36.4 & 107.8 & 33.8 \\
\hline $\mathrm{H}$ & 19.5 & 78.3 & 26.1 & 104.6 & 24.9 \\
\hline $\begin{array}{c}\text { Total, progressive } \\
(A, B, C, D)\end{array}$ & 41.5 & 188.8 & 18.0 & 81.6 & 22.0 \\
\hline $\begin{array}{c}\text { Total, regressive } \\
(E, F, G, H)\end{array}$ & 58.5 & 75.0 & 82.0 & 105.2 & 78.0 \\
\hline
\end{tabular}

*dominating demographic types of small cities according to the $K$. Doi procedure in bold Source: personal calculations based on Central Statistical Office of Poland 2014 


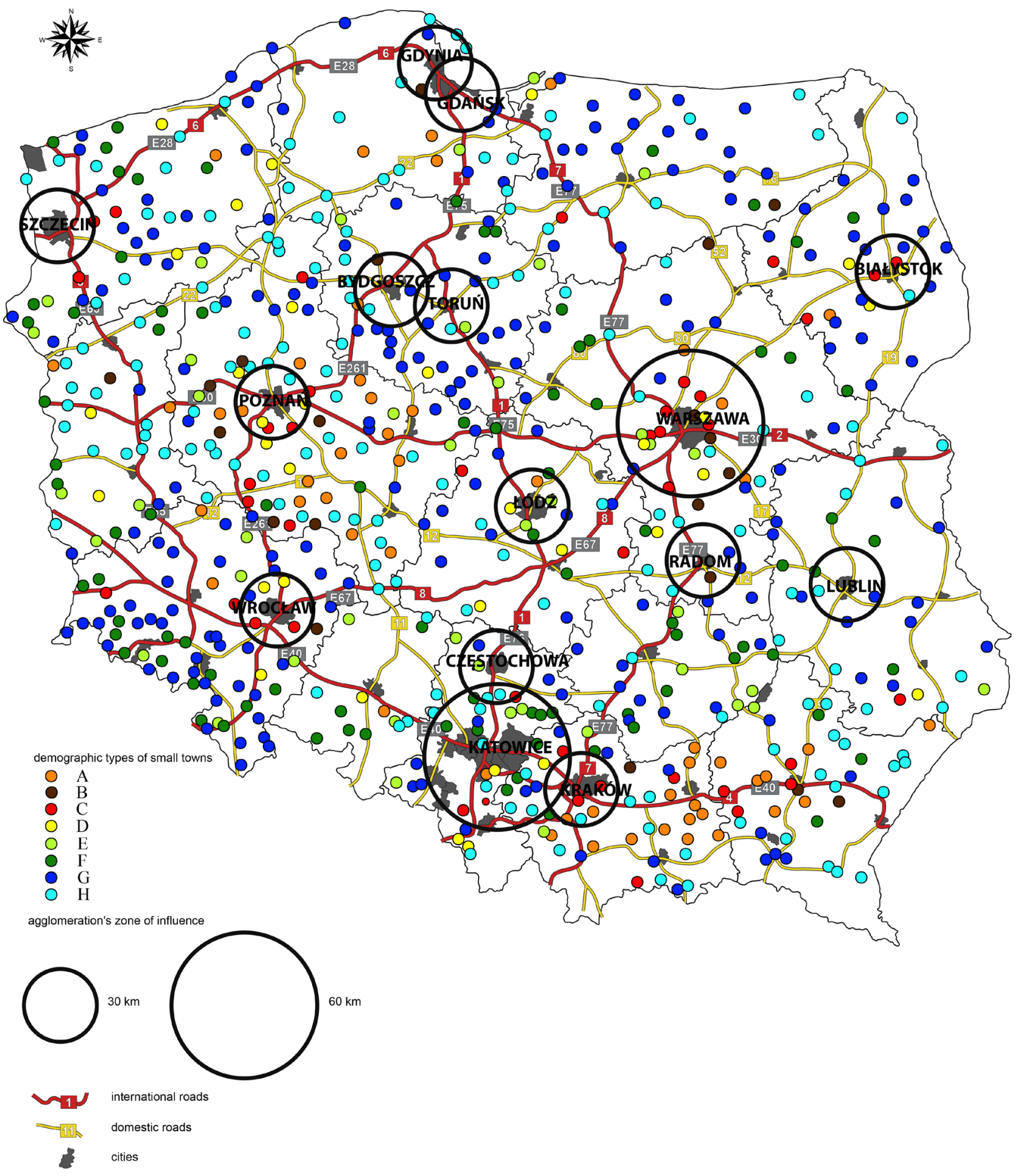

Figure 2. Demographic types of small cities in Poland in 2013 Source: personal research

of regressive areas was lower (total departure from average indicator $-75.0 \%)$. It was higher for cities located outside of these zones (105.2\%). Small cities qualified as progressive were determined to have a considerably higher share in the structure of areas near agglomerations than that of the entire surveyed group (total departure from average indicator $-188.8 \%$ ). The highest departure from average for all of the surveyed areas $(291.7 \%)$ was presented by cities classified as type C. Furthermore, type D $(220.3 \%)$ and type B (197.7\%) areas showed considerable departure (indicator over 150\%). Meanwhile, the share of progressive cities among areas located outside of the impact zones of agglomerations was lower than that of all of the surveyed settlements (total departure from average indicator $-81.6 \%$ ). 
Summary and conclusions In light of the analyses above, the following can be stated:

1. Small cities play an important role in the Polish settlement system. They compose $3 / 4$ of all urban areas and their inhabitants compose $1 / 5$ of the urban population. This presents the conclusion that their demographic processes have considerable impact on the formation of the domestic population and economic potential.

2. The small cities of Poland in $\mathbf{2 0 1 3}$ were represented by all demographic types. They were dominated by regressive types, which were identified in $80 \%$ of small cities. The structure was led by type $G$ where the negative natural increase did not exceed the negative migration balance, type $\mathrm{H}$ where the negative migration balance was not compensated by positive natural increase, and type $\mathrm{F}$ where the negative natural increase exceeded the negative migration balance. The leading elements composed $61.6 \%$ of all cities. Only $20 \%$ of small cities were qualified as progressive.

3. The main element determining the population trends of small cities was negative migration balance, which was observed in $80 \%$ of the surveyed areas. It should also be noted that such migration deficiency was shown by all of the demographic types classified as leading elements. $58 \%$ settlements presented negative natural increase. In almost $47 \%$ of the analysed cities, the negative migration balance was supported by negative natural increase. Slightly over $9 \%$ saw the population determined by the positive migration balance and positive natural increase. The great significance of the negative migration balance in the formation of the population trends of small cities does not project favourably for the future. According to Ravenstein's theory (1885), most emigrants are young, especially women. This entails a dropping birth factor and acceleration of population drop, which in turn reduces the demand for goods and services, limiting the development of enterprises and the social and technical infrastructure. These processes may block the sustainable development of small cities.

4. The performed procedures failed to show any statistically relevant relation between the city sizes and the demographic types. Regardless of the sizes, the leaders were the regressive types $\mathrm{G}$ and $\mathrm{H}$ with share between $48 \%$ for the smallest cities (population under 2 thousand) to $62.1 \%$ for the biggest ones (population between 10 and 20 thousand). The leading elements of cities with population between 2 and 5 thousand and 5 and 10 thousand also included the progressive type $A$, where the negative migration balance was compensated by the positive natural increase. However, the share of such cities failed to exceed $12 \%$.

5. Both small cities located along main roads and those located far from them were dominated by regressive types, which composed $75.1 \%$ of the first subgroup and $79.8 \%$ of the second one. However, it should be noted that $45 \%$ of all progressive cities and $38 \%$ of all regressive cities were located near roads, which provides the conclusion that the location of small cities near communication routes has positive effect on the demographic structures of the analysed areas. This was also confirmed by the analysis of total departures from the average. It was established that settlements located along domestic and international roads presented overrepresentation of progressive cities, especially type $\mathrm{C}$, in relation to the entire group of analysed areas.

6. Areas in the impact zones of agglomerations and outside of them were both mostly by regressive, but their share in the cities located in suburban areas was only $58.5 \%$ and as high as $82 \%$ outside of them. Therefore, the share of progressive areas within the impact zones of urban agglomerations was $41.5 \%$ and only $18 \%$ outside of them. It is possible to state that the small cities near agglomerations present more positive demographic trends than those in other locations. This was also confirmed by the analysis of total departures from the average. It showed that there was great overrepresentation of progressive types in the subgroup of suburban cities in relation to the entire group of the analysed areas. The greatest overrepresentation was demonstrated by cities classified as types B, C, and D, all of which presented an additional migration balance. Therefore, it is possible to assume that location near agglomerations realises the settlement attractiveness of small cities.

7. The performed analysis provides the conclusion that the size of small cities has only small impact on the population trends. Their main determinant is the distance from agglomerations and main roads. The comparison of the total departure from the average of small cities located along domestic and international roads and in suburban areas confirms the theses that the proximity of big urban areas provides for positive demographic transformations in the analysed settlements more frequently than the neighbourhood of main communication routes.

\section{References}

Alston, M 2004, You don't want to be a check-out chick all your life: The out-migration of young people from Australia's small rural towns', Australian Journal of Social Issues, vol. 39, no. 3, pp. 299-313.

Bagiński, E 1998, Małe miasta w sieci osiedleńczej Polski, Oficyna Wydawnicza Politechniki Wrocławskiej, Wrocław.

Baker, J (ed.) 1988, 'Small town Africa', Seminar Proceedings, no.23, The Scandinavian Institute of African Studies.

Bartosiewicz, B \& Marszał, T (ed.) 2011, Kierunki i uwarunkowania rozwoju małych miast $z$ perspektywy 20 lat transformacji, Uniwersytet Łódzki, Łódź.

Bogacz, T \& Żłobińska, K 2006, 'Warunki rozwoju małych miast w obrębie wrocławskiego obszaru metropolitalnego (wybrane przykłady)', Biuletyn KPZK PAN, z. 226, Warszawa, s. 67-80.

Brezzi, M, Dijkstra, L \& Ruiz, V 2011, 'OECD extended regional typology: The economic performance of remote rural regions', OECD Regional Development Working Papers, no. 2011/06, OECD Publishing.

Central Statistical Office of Poland 2014. Available from: <http://www.stat.gov.pl>. [7 September 2014]

Čermák, Z, Hampl, M \& Müller, J 2009, 'Contemporary tendencies of population development of metropolitan areas in Czechia: is an important turn coming?' - GeografieSborník ČGS, vol. 114, no. 1, pp. 37-51.

Cheshire, P \& Magrini, S 2004, Population growth in European cities: weather matters - but only nationally, Department of Geography \& Environment, London School of Economics, London.

Choguill, C 1989, 'Small towns and development: A tale from two countries', Urban Study, vol. 26, no. 2, pp. 267-274.

Daniels, T \& Lapping, M 1987, 'Small town triage: a rural settlement policy for the American Midwest', Journal of Rural Studies, vol. 3, issue 3, pp. 273-280. 
Dijstra, L \& Poelman, H 2008, 'Remote rural regions. How proximity to a city influences the performance of rural regions', European Union Regional Policy, no. 1.

Domański, B 2001, Kapitał zagraniczny w przemyśle Polski. Prawidłowości rozmieszczenia, uwarunkowania i skutki, IGiGP UJ, Kraków.

Domhardt, HJ \& Troeger-Wei BG 2009, 'Germany`s shrinkage on small scale' in The future of shrinking cities: problems, patterns and strategies of urban transformation in a global context, Berkeley CA, eds K Pallagst, J Aber, I Audirac \& et al., Center for Global Metropolitan Studies, Institute of Urban and Regional Development, University of California Berkeley and the Shrinking Cities International Research Network, pp. 161-168.

Duranton, G \& Puga, D 2004, 'Microfoundations of urban agglomeration economies' in Handbook of Regional and Urban Economics, ed. 1, vol. 4, chapt. 48, eds JV Henderson \& JF Thisse, Elsevier, pp. 2063-2117.

Dziewoński, K 1962, 'Procesy urbanizacyjne we współczesnej Polsce', Przegląd Geograficzny, t. 34, z. 3, s. 459-508.

Dziewoński, K 1983, 'Geografia osadnictwa i ludności w Polsce w latach 1945-1982. Mechanizmy rozwoju', Przegląd Geograficzny, t. 55, z. 3-4, s. 547-569.

Easterlin, RA 1962, 'Kuznets cycles in U.S. Population growth and fertility', in The American Baby Boom in Historical Perspective, National Bureau of Economic Research, Inc, pp. 2-13.

Exploring Urban Futures in European Cities: A Social CohesionBased Approach, 2011, URBAN-NET, Deliverable 4.5.

Fonseca, ML 2008, 'New waves of immigration to small towns and rural areas in Portugal', Population, Space and Place, Special Issue: International Migration to Non-Metropolitan Areas, vol. 14, issue 6, pp. 525-535.

Fésüs, G, Rillaers, A, Poelman, H \& Gáková, Z 2008, 'Regions 2020. Demographic challenges for European regions', Background document to commission staff working document 2868 Final Regions 2020, an assessment of future challenges for $E U$ regions.

Fuguitt, GV, Brown, DL \& Beale, CL 1989, Rural and Small Town America, Russell Sage Foundation, New York.

Fuguitt, GV \& Heaton TB 1995, 'The impact of migration on the nonmetropolitan population age structure, 1960-1990', Population Research and Policy Review, no. 14, pp. 215232.

Gabriel, M 2002, 'Australia's regional youth exodus', Journal of Rural Studies, no. 18, pp. 209-212.

Glock, B 2006, Stadtpolitik in schrumpfenden Städten. Duisburg und Leipzig im Vergleich, Wiesbaden: VS, Verlag für Sozialwissenschaften.

Górecka, S \& Kozieł, R 2004, 'Procesy demograficzne w największych miastach Polski $w$ okresie transformacji' $w$ Przemiany demograficzne i jakość życia ludności miast red. J Słodczyk \& D Rajchel, Uniwersytet Opolski, Opole.

Graeme, H \& Morén-Alegret, R 2008, 'International migration to non-metropolitan areas of high income countries: editorial introduction', Population, Space and Place, Special Issue: International Migration to Non-Metropolitan Areas, vol. 14, issue 6 , pp. $473-477$

Hägerstrand, T 1957, 'Migration and area. Survey of a sample of Swedish migration fields and hypothetical considerations on their genesis' in Migration in Sweden: A symposium, eds D Hannerberg, T Hagerstrand, Ä \& B Odeving, pp. 27-158, Lund, Sweden, Gleerup

Heffner, K 2008, 'Funkcjonowanie miast małych w systemie osadniczym Polski w perspektywie 2033 r.', w Ekspertyzy do koncepcji przestrzennego zagospodarowania kraju
2008-2033, Tom I, red. K. Saganowski, M ZagrzejewskaFiedorowicz \& P Żuber, Ministerstwo Rozwoju Regionalnego, Warszawa, s. 281-333.

Heffner, K \& Czarnecki, A 2004, Contribution to Final Report „The Role of Small and Medium Size Towns in Rural Development in Poland", IRWiR PAN, Warszawa.

Johnson, K 2006, 'Demographic trends in rural and small town America', Reports on Rural America, vol.1, no. 1, Carsey Institute, University of New Hampshire.

Kachniarz, T, Makowska, K \& Szymkiewicz, E 1996, Małe miasta przemysłowe, IGPiK, Warszawa

Kamarai, G 2011, 'Demographic evolution of the small towns in the north-east development region in the post-communist period', Romanian Review of Regional Studies, vol. VII, no. 2.

Kantor-Pietraga, I 2014, 'Systematyka procesu depopulacji miast na obszarze Polski od XIX do XXI wieku', Prace Naukowe Uniwersytetu Śląskiego, nr 3158, Katowice.

Kantor-Pietraga, I, Krzysztofik, R \& Runie, J 2012, 'Kontekst geograficzny i funkcjonalny kurczenia się małych miast w Polsce południowej' w Ewolucja funkcji małych miast w Polsce, red. K Heffner \& A Halama, Studia Ekonomiczne, Zeszyty Naukowe Wydziałowe, Wydawnictwo UE, Katowice, s. 9-24.

Knox, PL \& Mayer, H 2009, Small town sustainability: economic, social, and environmental innovation. Basel: Birkhauser Verlag.

Kozłowski, L 2007, 'Miasteczka rolnicze w Polsce. Geneza i trwałość funkcji rolniczej miast' w Podstawy i perspektywy rozwoju małych miast, red. E Rydz, Akademia Pomorska w Słupsku, Słupsk, s. 109-136.

Kwiatek-Sołtys, A 2000, 'Przemiany demograficzne małych miast województwa małopolskiego', Rocznik Nauk.-Dydakt. AP, Kraków, z. 209, Prace Geogr. XVIII, Kraków, s. 15-28.

Kwiatek-Soltys, A 2004, 'Przemiany struktur ludnościowych w małych miastach powiatowych w Polsce w latach 1992-2002' w Przemiany demograficzne i jakość życia ludności miast, red. J Słodczyk \& D Rajchel, Uniwersytet Opolski, s. 51-59.

Morén-Alegret, R 2008, 'Ruralphilia and urbophobia versus urbophilia and ruralphobia? Lessons from immigrant integration processes in small towns and rural areas in Spain', Population, Space and Place, Special Issue: International Migration to Non-Metropolitan Areas, vol. 14, issue 6 , pp. 537-552.

Mykhnenko, V \& Turok, I 2008, 'East European Cities: Patterns of Growth and Decline, 1960-2005', International Planning Studies, 13 (4).

Parr, JB 1973, 'Growth poles, regional development, and central place theory', Papers of the Regional Science Association, vol. 31, pp. 173-212.

Partridge, M, Bollman, RD, Olfert, MR \& Alasia, A 2007, 'Riding the wave of urban growth in the countryside: Spread, Backwash, or Stagnation?', Land Economics, vol. 83(2), pp. 128-152.

Population and the American Future, 1972, The Report of The Commission on Population Growth and the American Future, The Rockefeller Commission, Washington.

Ramsey, RJ 1967, 'Services and environmental adjustments needed by rural youth who move to urban communities', National Outlook Conference on Rural Youth, October 23-26, Washington.

Ravenstein, EG 1885, 'The laws of migration', Journal of the Royal Statistical Society, 48, pp. 198-199.

Runie, A 2013, 'Rola miast średnich w kształtowaniu systemu osadniczego Polski', Prace Wydziału Nauk o Ziemi Uniwersytetu Śląskiego, Uniwersytet Śląski, Katowice. 
Runie, J 2007, Metody badań w geografii społeczno-ekonomicznej - elementy metodologii, wybrane narzędzia badawcze, Wydawnictwo Uniwersytetu Śląskiego, Katowice.

Tacoli, C 2004, 'The role of small and intermediate urban centers and market towns and the value of regional approaches to rural poverty reduction policy', Prepared for the OECD DAC POVNET Agriculture and Pro-Poor Growth Task Team Helsinki Workshop 17-18 June. Available from: <www.oecd. org/dac/povertyreduction/36562990.pdf>. [29.07.2014].

Titus, M \& Hinderink, J 2002, 'Small towns and regional development: major findings and policy implications from comparative research', Urban Studies, vol. 39, pp. 379-391.

Tonts, M 1996, 'Economic restructuring and small town adjustment: Evidence from the Western Australian central wheatbelt', Rural Society, vol. 6, no. 2, pp. 24-33.

Webb, JW 1969, 'The natura and migrational components of population changes in England and Wales, 1921-1931', Economic Geography, vol. 2.

Veneri, P \& Ruiz, V 2013, 'Urban-to-rural population growth linkages: evidence from OECD TL3 regions', OECD Regional Development Working Papers, 2013/03, OECD Publishing.

Winiarczyk-Raźniak, A \& Raźniak, P 2012, Migracje wewnętrzne ludności w polskich obszarach metropolitalnych u progu XXI wieku, Wyd. UP, Kraków. 